\title{
Ecclesiastical Law Society Day Conference: Gospel and Law in Theological Education
}

\author{
St Bride's Institute, London, I7 March 2018
}

RUSSELL DEWHURST

Rector of Ewell

As its constitution makes clear, the object of the Ecclesiastical Law Society is 'to promote education in ecclesiastical law for the benefit of the public'. The Society's 31st annual conference was, therefore, a return to its core area of interest as it discussed the topic of 'Gospel and law in theological education'.

The first business of the day was a magnificent keynote address delivered by Dr Andrea Russell, Tutor for Anglican Admissions and Director of Studies at the Queen's Foundation, Birmingham, on the topic of 'Church law and ministerial education'. Dr Russell talked about the challenges of teaching canon law to ordinands drawn from across the range of church traditions and cultures. She drew extensively on Richard Hooker's teaching about order, suggesting that the legal order is one of the ways in which God is revealed to us, and that legal order is part of mutual accountability. Of particular interest were the examples by which Dr Russell demonstrated how she encouraged those ordinands who may be suspicious of the concept of canon law to engage with the material theologically and pastorally.

The Ven Simon Baker, Archdeacon of Lichfield, and the Revd Canon Norman Boakes, Archdeacons' National Executive Officer, gave a paper on 'Good practice in the conduct of ordained ministry'. The session began with a close reading of the Rule of St Benedict on order as the framework for flourishing. The two speakers then reflected on the many ways in which the role of a Christian minister is unique, including the work situation and the relationships and roles which ministry involves.

At the Annual General Meeting of the Society, as well as election of officers and committee members, the main business was the proposal to convert the Society from an unincorporated association to a charitable incorporated organisation. The relevant motions were passed unanimously. At the conclusion of the 
AGM, the newly re-elected ELS chairman, Mark Hill, launched the fourth edition of every Anglican canonist's vade mecum, Ecclesiastical Law.

After lunch, Stephen Borton, Ecclesiastical Manager at Lee Bolton Monier-Williams, demonstrated some of the training that is provided (in some dioceses) to curates at Initial Ministerial Education (IME) 5/6 in the forms of 'Training materials on marriage law'. Stephen also shared insights on recent developments of marriage law. The Ven Peter Rouch, Archdeacon of Bournemouth, led our groupwork session, in which we discussed case studies that might arise in the Church of England. The case studies, all drawn from real-life examples, ranged from the uncertain status of land used for a garden of remembrance, fees retained by a member of the clergy officiating at funerals in an allegedly private capacity, and the constitution of a parochial church council. The lively discussion demonstrated the importance of education in ecclesiastical law in the life of ministers and parishes. Ignorance of the law can have serious pastoral consequences and can even, as in the case of misappropriation of fee income, lead to a term of imprisonment.

The last presentation of the day saw Simon Baker and Stephen Borton return to the lectern to explain some of the work of the Society's Education subcommittee. Delegates' attention was drawn in particular to the growing range of material, including training presentations and links to legal resources, now hosted on the Society's website (www.ecclawsoc.org.uk). Everyone present was encouraged to evangelise about the work of the Society to the church at large, to ensure that the availability of these resources should become better known. After tea, the day conference concluded with evening prayer in St Bride's church.

What emerged strongly from the day as a whole was the continuing importance of excellent education in ecclesiastical law. Law is becoming, if anything, more important in the day-to-day life of the Church, and yet the availability of education for clergy and lay officers is patchy at best. A church which provides inadequate training for its ministers in this basic area of competence is derogating from its duty of care. The many excellent examples of good practice that were shared through the day, however, were a source of encouragement. The Society's core aim - promoting education in ecclesiastical law- remains as relevant as ever. 